\title{
Biomolecular Aspect of Apoptosis Pathway: Caspase-8 and Caspase-9 on Polifenol Exposure of Phaleria macrocarpa (Scheff.) Boerl. on Mice Balb/c
}

\author{
Theopilus Wilhelmus Watuguly \\ General Biology Laboratory, Universitas Pattimura, Ambon, Moluccas Province, Indonesia
}

Copyright $\mathrm{O} 2018$ by authors, all rights reserved. Authors agree that this article remains permanently open access under the terms of the Creative Commons Attribution License 4.0 International License

\begin{abstract}
Objective: The Polyphenol compound of Phaleria macrocarpa has potential as an anticancer agent, and it has shown to inhibit lung carcinogenesis. The objective of this study was to elucidate the role of polyphenol induced apoptosis via caspase- 8 and caspase- 9 . Methods: Balb/c mice were randomly divided into 2 groups: Group 1: control group with administration of sterile aquades and group 2: treatment group with administration of $50 \mathrm{mg}$ polyphenols. The development of lung tumors was confirmed by observing post-operation tissue at week 8, 17 and 26. The expression of caspase- 8 and caspase- 9 were assayed. Data was analyzed using Kruskal-Wallis, Mann-Whitney, one way ANOVA, Post hoc LSD test, with a significance level of $p<(0.05)$. Results: Administration of $50 \mathrm{mg}$ polyphenols from $P$. macrocarpa extract, showed inhibition of lung carcinogenesis through increased expression of caspase- 8 and caspase-9 in the treatment group at week 8, 17 and 26 $(\mathrm{p}=0.000)$. Conclusion: The administration of poliphenol from $P$. macrocarpa extract was shown to effectively inhibited lung carcinogenesis through increased of caspase- 8 and caspase- 9 in mice strain Balb/c.
\end{abstract}

Keyword Polyphenols, Phaleria macrocarpa, Lung Carcinogenesis, Caspase-8, Caspase- 9

\section{Background}

Chemoprevention by the use of natural materials (phytochemicals) has been shown to inhibit long cancer progression. According to [1], defects in apoptotic mechanisms are known to be important causes of carcinogenesis. Cancer cells require resistance to apoptosis through overexpression of antiapoptosis proteins and/or through decreases or mutations of proapoptotic proteins.

P53 induced apoptosis is required to eliminate the aberrant cells. Bax, which is a pro-apoptotic member of the Bcl-2 family, also appears to be a target of p53 and is up-regulated in some systems during p53-mediated apoptosis. On the other hand, up-regulation of Bax and down-regulation Bcl-2 expression may lead to up-regulation of caspase- 9 thus activating caspase- 3 during apoptosis [2]. According to [3], [4], the role of p53 in apoptosis is quite complex and includes the pathway of death receptors and mitochondrial pathways. In the death receptor pathway, p53 can initiate this pathway in response to DNA damage P53 may activate protein Fas/CD95 as target gene Directly by p53, where through the Fas protein, caspase- 8 can be activated resulting in the process of cell death/apoptosis [5].

Various studies indicate that natural materials can modulate the complex multiscale processes of carcinogens [6]. Several studies began to be directed at testing the potential of natural materials as chemopreventive agents that have potential as chemotherapeutic agents.

Ultimately, the goal of using natural products is to increase the sensitivity of cancer cells and reduce the side effects of conventional chemotherapeutic agents. Polyphenolic compounds are natural phenolic that have anticancer properties and are potential inhibitors of cancer cell growth [7]; [8]. Research conducted by [9] showed that polyphenols function as anticancer and play a role in cancer prevention. As anticancer, the polyphenols from God's crown plant or Phaleria macrocarpa are expected to induce apoptosis.

Phaleria macrocarpa (Mahkota Dewa or god's crown Plant) is an indigenous medicinal plant of Indonesia and has been known to empirically have anticancer activity and inhibit cancer growth in previous studies [10]; [11]; [12]; [13]. Based on phytochemical analysis and standardization, polyphenols are one of the main compounds found in the $P$. macrocarpa [14]; [15; [13]. This inhibition is thought to be related to the role of polyphenols in the $P$. macrocarpa, for that to be tested in-vivo. The objective of the study was to 
find out that the polyphenols of the P.macrocarpa could induce apoptosis through increased caspase- 8 and caspase- 9 expression in Balb/c mice via histopathology observation.

\section{Method and Material}

Animal Experiments: Balb/c 1-2-week, weighing 20-30 gram weight were obtained from UGM Laboratory (LPPT-IV). Mice feed for maintenance during treatment and observation in the laboratory was obtained from LPPT Unit IV UGM. Benzo(a)Pyrene (BaP) 1x1 gram to induce lung cancer was obtained from SIGMA-ALDRICH USA (catalog number: B1760-1G).

In this study, Ethical clearance for experimental animal use in research has been obtained from the Health Research Ethics Commission (KEPK) of the Faculty of Medicine, Diponegoro University at Dr. Kariadi hospital Semarang, Reg. No. 38 / EC / FK / RSDK / 2010. Week 4 after subcutaneous injection in sub-scapula, Balb/c were divided into 2 randomized study groups. In the treatment group, polyphenol crown of god $1 \mathrm{x} /$ day, with a dose of $0.021 \mathrm{x}$ every day. This treatment was carried out for 24 weeks. Each animal from 2 groups (BP control and treatment [BP + polyphenol $50 \mathrm{mg}]$ ), terminated at weeks 8,17 and 26 for observation of different parameters. The total number of experimental animals was $30(\mathrm{~N}=30, \mathrm{n}=5$ for each time point), plus 8 for the first and second surgery aimed at knowing that the mice had entered hyperplasia, resulting in 40 animals. Dropouts were performed on 2 mice that died after induction of Benzo(a)Pyrene (BaP) stage 2 .

Experimental Design: total of $40 \mathrm{Balb} / \mathrm{c}$ 1-2 weeks old were adapted for a week by sterilization with adequate lighting. Induction of lung tumor was done according to carcinogen test conducted by [16]; [17]; [18]. The first induction was performed on day 1 with a dose of 0.2 $\mathrm{ml} / 0.025 \mathrm{cc}$. Second induction at day 8 with dose 0,4 $\mathrm{ml} / 0,025 \mathrm{cc}$ and third induction at day 15 with dose 0,8 $\mathrm{ml} / 0,025 \mathrm{cc}$. Each mice received subcutaneous lung tumor induction at the subscapular region with $0.1 \mathrm{ml}$ of the concentration suspension $\mathrm{B}(\mathrm{a}) \mathrm{P} \quad 0.2 \mathrm{mg}$ dissolved in DMSO (single dose). Carcinogens are used within 1 hour after emulsification. After injection, the mice were left alive with their mother, fed water and food ad libitum during the weaning process. DMSO was used as dilution solution and dissolved the $\mathrm{BaP}$ (inductor). Further, 8 mice were sacrificed to be able to ascertain the growth of tumor successively in the 4th and 5th weeks; to better observe the development of carcinogenesis entering stage of hyperplasia and dysplasia in mice epithelial cells. Beginning of week 5, Balb/c had entered the hyperplasia stage, were divided into 2 groups at random.

Mice from 2 groups (control and treatment) were terminated at 8th, 17th and 26th weeks for stages of developmental studies. The entire lung organ was excised and washed with $0.9 \% \mathrm{NaCl}$ solution, dried and fixed with $10 \%$ buffer formaldehyde solution for 24 hours and were ready for paraffin blocks. 5 lung lobes were cut on each slide size 4 microns with 4 pieces of tissue and observations were made. The next process, the network was processed into histologic preparations through stages of fixation, dehydration, impregnation and embedding. The tissues of the 2 groups that had been made into paraffin blocks were cut 4 microns thick and then stained with Hematoxylin Eosin $(\mathrm{H} \& \mathrm{E})$ to calculate the incidence of hyperplasia and dysplasia of the bronchiolar epithelium in lung tissue by light microscopy using 400x magnification. The last process, each paraffin block were cut again into 4 microns thick, histopathology preparations were made for immunohistochemistry (IHC) (the procedure attached). The Preparations were further studied by conducting observations using a light microscope. Positive cell count calculations expressed p53 (wild type), Bcl-2 and Bax, caspase-3,-8,-9 proteins using a light microscope with 400x enlargement in 5 fields of view. The cell cytoplasm that expresses the protein were shown in a brownish color.

Immunohistochemistry: IHC Painting used antibodies labeled horseradish peroxidase enzymes. These antibodies will be bound to their specific proteins. In cells that express proteins positively, labeled enzymes on antibodies recurred with DAB chromogen into brown substrate, otherwise in cells with negative expression appeared purple.

Immunohistochemical immunization was scored according to the number of positive cells colored per 100 cells calculated. Caspase- 8 and caspase-9 immunoreactivity were considered negative (0) when there was no staining; Weak (1) when the staining was focal and rather intense; Moderate (2) when about two-thirds of the cells were sufficiently stained; Strong (3) when the majority of cells ( $>$ two/thirds) were intensely stained. This inspection procedure is in accordance with that of [19]; [20].

Statistical Analysis: Caspase-8 and caspase-9 data are ratio scales. The data were analyzed descriptive analysis in the form of mean, median, mode and standard deviation, then assessed to have normal distribution or not by assessing histogram and box plot. Before it was analyzed, the normality test and homogeneity test were done earlier on the data. Data analysis included Kruskal-Wallis non-parametric test followed by Mann-Whitney test for Cas-8 and Cas-9 while parametric One Way Anova (Analysis of Variance) test, followed by different test between groups with Post Hoc Test LSD (Least Square Difference ) With significance level $\mathrm{p}<0,05$ and $95 \%$ confidence interval. Data obtained statistically using SPSS 19.

\section{Results and Discussion}

\section{Research result}




\section{Expression Caspase-8}

The role polyphenols of the $P$. Macrocarpa to caspase- 8 expression was assessed by immunohistochemical analysis which aimed at the evaluation of histopathological observations. Based on observations on caspase- 8 expression, there was an increase in caspase- 8 expression in the treatment group. Figure 1 shows that the number of positive cells in the bronchiolar region is reduced in the group treated with polyphenolic from Mahkota Dewa or god's crown plant when compared with the carcinogen control group.

In the carcinogen control group, caspase- 8 expression respectively at week 8 was $0.32 \pm 0.10$, at week 17 of 0.36 \pm 0.08 and $0.72 \pm 0.30$ at week to -26 . The control group appeared relatively constant. The treatment group experienced a significant increase. In the polyphenol treatment group at week 8 of $0.64 \pm 0.16$, it increased at week 17 of $0.92 \pm 0.22$ and $2.02 \pm 1.05$ at 26 weeks (see boxplot chart 1). The results of the statistical tests using the Kruskal-Wallis Test showed significant improvement ( $\mathrm{p}=$ $0,000)$ by oral polyphenol against caspase- 8 expression during carcinogenesis. Further differences between the experimental groups were analyzed using the Mann-Whitney Test as will be discussed in the next section.
A

\section{Control}

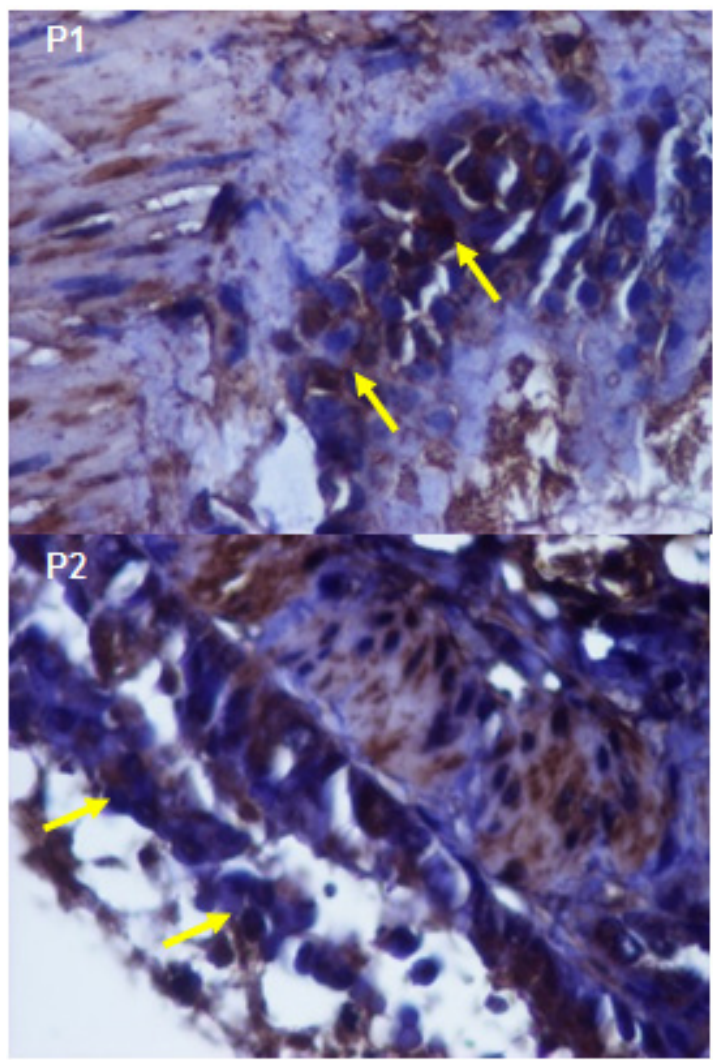

\section{Treatment}

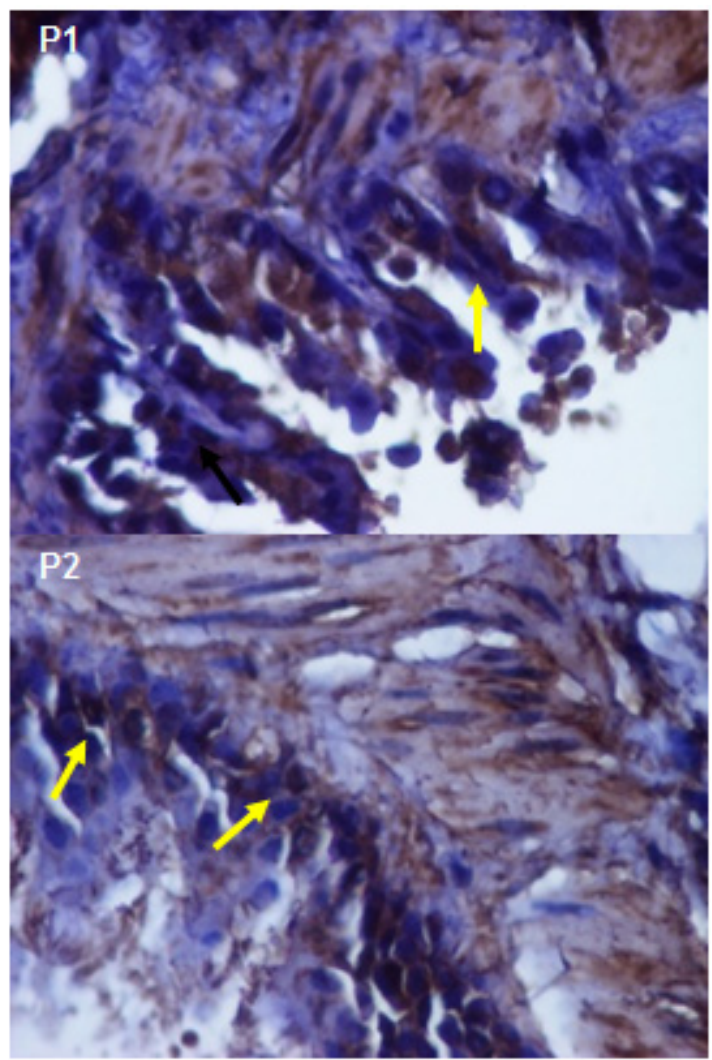


B

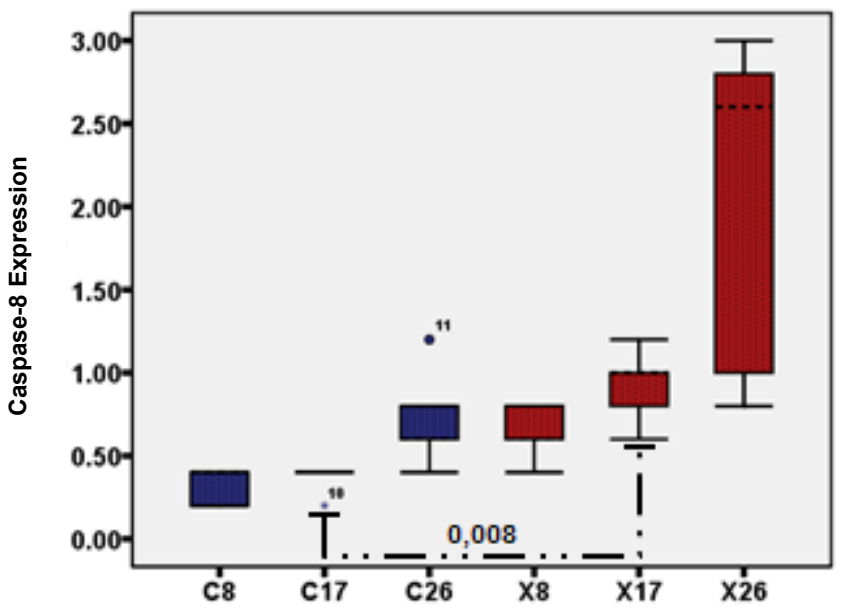

C

\begin{tabular}{|c|c|c|c|c|c|c|c|c|}
\hline \multirow{3}{*}{ No } & \multirow{3}{*}{ Group } & \multirow{3}{*}{ week } & \multicolumn{6}{|c|}{ group/week } \\
\hline & & & \multicolumn{3}{|c|}{ Control } & \multicolumn{3}{|c|}{ treatment } \\
\hline & & & 8 & 17 & 26 & 8 & 17 & 26 \\
\hline \multirow[t]{3}{*}{1.} & Control & 8 & - & 0,008 & 0,008 & 0,008 & 0,008 & 0,008 \\
\hline & & 17 & & - & 0,008 & 0,008 & 0,016 & 0,008 \\
\hline & & 26 & & & - & 0,032 & 0,008 & 0,008 \\
\hline \multirow[t]{3}{*}{2} & Treatment & 8 & & & & - & 0,016 & 0,008 \\
\hline & & 17 & & & & & - & 0,008 \\
\hline & & 26 & & & & & & - \\
\hline
\end{tabular}

Significant level $(\mathrm{p}>0,05)$

Research data, 2017

Figure 1. A. Immunohistochemical localization of lung-induced lung cell tissue induced by caspase- $8 \mathrm{BaP}$ in the carcinogen control group and the treatment group. Treatment with polyphenols results in increased caspase- 8 expression in the bronchiolar epithelium. The brown color of the cytoplasm indicates the presence of caspase- 8 expression. The cell core appears round-oval in brown (black arrow). Observations with 400X magnification. P1 shows the first surgery of the 8th week and P2 shows the third surgery of the 26th week. B. Boxplot graph of polyphenol effect of $P$. Macrocarpa on control group and treatment group on caspase- 8 expression on BaP-induced Balb / c strain of mice. C. Results of significance level of caspase- 8 expression in control group and treatment group.
Mann-Whitney Test, showing caspase- 8 expression was increased in the 8th, 17th and 26th treatment groups compared with the control group. Statistical test of significance level on caspase-8 expression showed significantly higher treatment group compared to control group. Test of significance level on caspase-8 expression showed significantly higher treatment group compared to control group. In the 8th week control group, the test results showed significant $(p=0.008)$ in the 17th and 26th week control groups, while significantly $(p=0.008)$ in the 8th, 17th and 26th treatment groups. -17, showed significant $(p=0,008)$ in all treatment groups both at weeks 8,17 and 26 . While control group week 26 , test result showed significant $(p=0,008)$ in whole weeks of treatment group.

At week 8, the control group test showed significant $(\mathrm{p}=$ $0,016)$ with treatment group. At week 17 , the control group test showed significant $(p=0,008)$ with treatment group. While week 26, the control group test showed significant ( $\mathrm{p}$ $=0,032$ ) with treatment group.

\section{Caspase-9 Expression}

The role polyphenols of $P$. Macrocarpa to caspase-9 expression was assessed by immunohistochemical analysis aimed at the evaluation of histopathological observations. Based on observations on caspase-9 expression, there was an increase in caspase-9 expression in the treatment group. Figure 2 shows that the number of positive cells in the bronchiolar area decreases in the treated group when compared with the carcinogen control group.

In the control group of carcinogens, the expression of caspase-9 protein each at week 8 was $0.32 \pm 0.10$, at week 17 of $0.48 \pm 0.22$ and $0.28 \pm 0.10$ at week To-26. In the control group it remained relatively constant, although at week 17 it was slightly elevated. In the polyphenolic treatment group each experienced a significant increase. In the polyphenol treatment group at week 8 of $0.56 \pm 0.16$ increased at week 17 of $1.00 \pm 0.20$ and $2.60 \pm 0.28$ at 26 weeks (see Boxplot 2 chart). The result of statistical test using Kruskal-Wallis Test showed significant improvement $(p=0,000)$ by oral polyphenol to caspase- 9 expression during carcinogenesis. Furthermore, further differences between the experimental groups were analyzed using the Mann-Whitney Test. 
$\mathbf{A}$
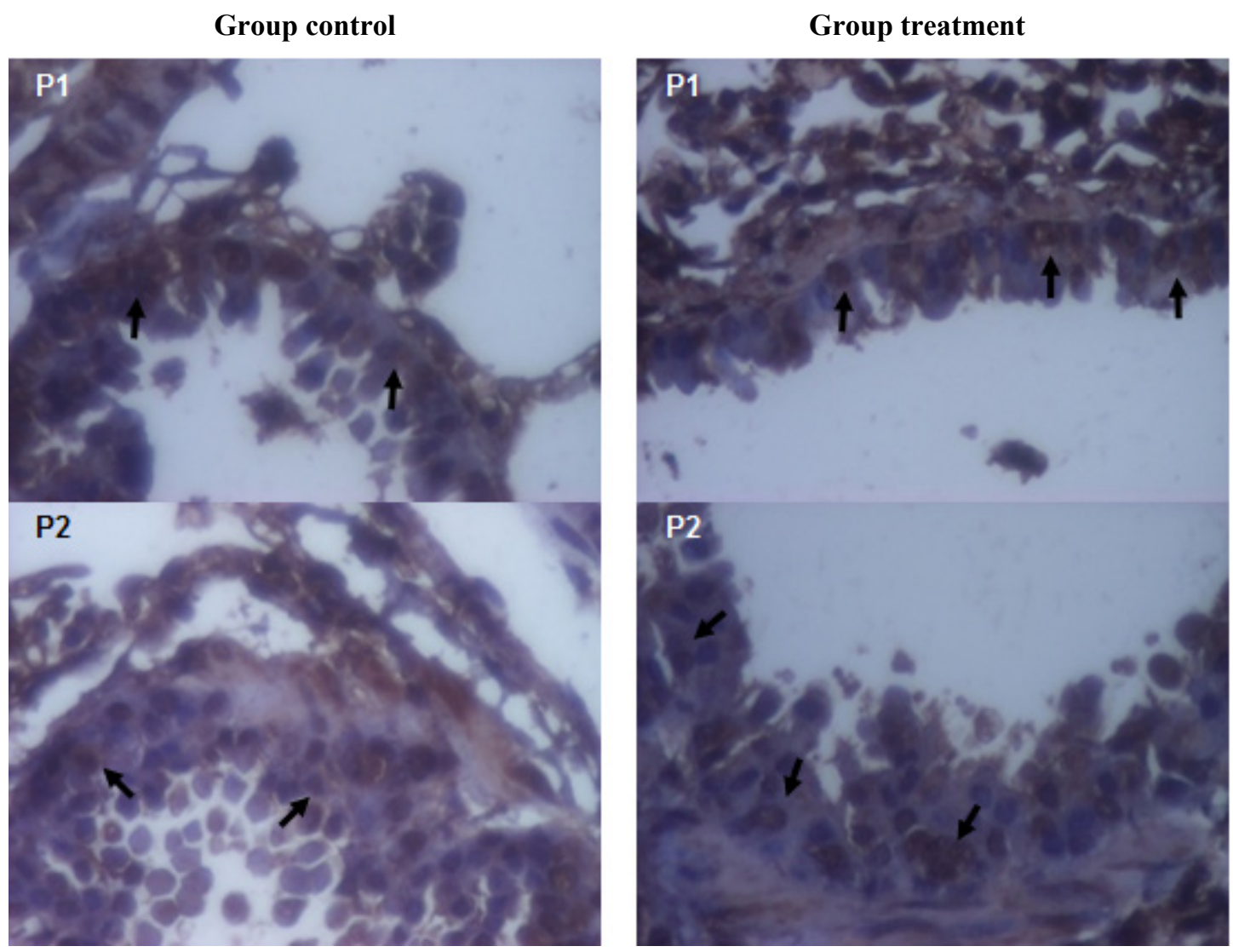

B

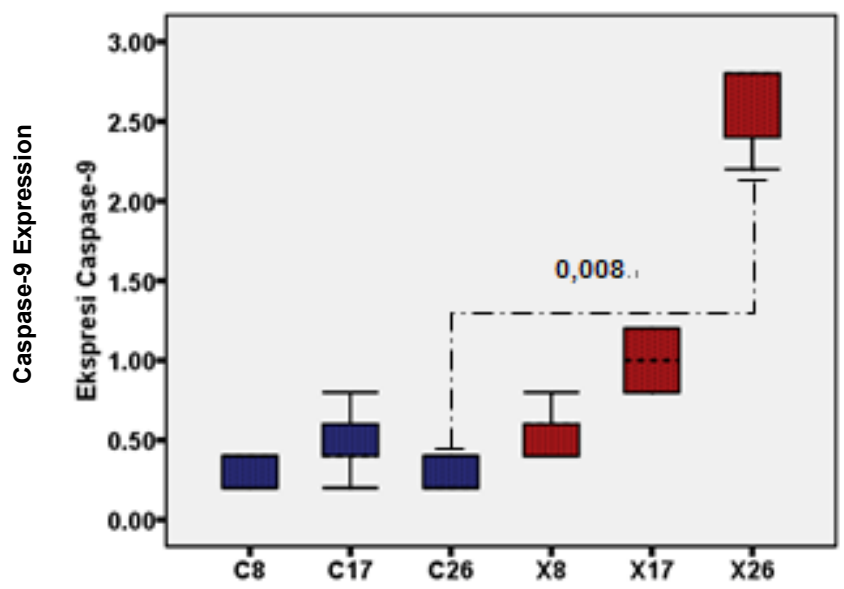

C

\begin{tabular}{|c|c|c|c|c|c|c|c|c|}
\hline \multirow{3}{*}{ No } & \multirow{3}{*}{ Group } & \multirow{3}{*}{ week } & \multicolumn{6}{|c|}{ Group/week } \\
\hline & & & \multicolumn{3}{|c|}{ control } & \multicolumn{3}{|c|}{ treatment } \\
\hline & & & 8 & 17 & 26 & 8 & 17 & 26 \\
\hline \multirow[t]{3}{*}{1.} & Control & 8 & - & $0,016^{*}$ & $0,008^{*}$ & $0,008^{*}$ & $0,008^{*}$ & $0,008^{*}$ \\
\hline & & 17 & & - & $0,008^{*}$ & $0,008 *$ & $0,016^{*}$ & $0,008 *$ \\
\hline & & 26 & & & - & $0,032 *$ & $0,008 *$ & $0,008 *$ \\
\hline \multirow[t]{3}{*}{2} & Treatment & 8 & & & & - & $0,016^{*}$ & $0,008 *$ \\
\hline & & 17 & & & & & - & $0,008 *$ \\
\hline & & 26 & & & & & & - \\
\hline
\end{tabular}

Significant level $(p>0,05)$

Research data, 2017 
Figure 2. A. Immunohistochemical analysis shows lung cell populations induced by caspase- 9 exposed $\mathrm{BaP}$ in the carcinogen control group and the treatment group. Treatment with polyphenols results in an increase in caspase-9 expression in the bronchiolar epithelium. The brown color of the cytoplasm indicates a caspase-9 expression. The cell core looks round-oval in blue-purple (black arrow). Observations with 400X magnification. P1 shows the first surgery of the 8th week and P2 shows the third surgery of the 26th week. B. Boxplot graph of polyphenol effect of crown of god on control group and treatment group on caspase-9 expression on BaP-induced Balb / c strain of mice. C. Results of significance level of caspase-8 expression in control group and treatment group.

Mann-Whitney Test, showing the caspase-9 expression was elevated in the treatment groups at weeks 8, 17 and 26 compared with the control group. Statistical test of significance level on caspase-9 expression showed significantly higher treatment group compared to control group.

Test of significance level on caspase- 8 expression showed significantly higher treatment group compared to control group. In the 8 th week control group, the test results showed significant $(p=0.016)$ in the control groups at weeks 17 and 26 , whereas significantly $(\mathrm{p}=0.008)$ showed in the 8th, 17th and 26th treatment groups. -17 , showed significant $(p=0,008)$ in all treatment groups both at weeks 8,17 and 26 .

At week 8 , the control group test showed significant $(\mathrm{p}=$ $0,056)$ with treatment group. At week 17, the control group test showed a significant $(p=0.016)$ with the treatment group. While week 26, the control group test showed significant $(p=0,008)$ with treatment group.

\section{Discussion}

In this study, caspase- 8 and caspase- 9 expression in pulmonary carcinogenesis was observed after IHC painting using antibodies labeled horseradish peroxidase enzyme. These antibodies were bound to their specific proteins. In cells that express proteins positively, enzymes labeled on antibodies recurred with $\mathrm{DAB}$ chromogen into brown substrate. In contrast to cells that are negative expression will look purple.

Caspase is activated either by the activation of death receptor (DR) (extrinsic) or by mitochondrial release from apoptogenic proteins (e.g. cytochrome c, smac/DIABLO, and $\mathrm{HtrA} / \mathrm{Omi}$ ) (intrinsic). Signals propagated by intrinsic pathways may also be produced in the cell nucleus or lysosomes or in the endoplasmic reticulum [21]. Caspase-8, -9 in human cells, which at the time of activation divided and activated the second group, the effector caspases (especially caspase-3 in human cells), which then performed selective proteolysis [22]. Therefore, up-regulation in both caspase- 8 , -9 and caspase- 3 is an important phenomenon for apoptotic induction. Caspase-8 and -9 are basic caspases that are recruited on the DISC. In TNFR1, TNF bonds induce recruitment of two signaling molecules, TNFR1-associated death protein (TRADD) and Fas- associated protein with death domain (FADD). Procaspase-8 is then recruited to the DISC complex via death effector domain (DED) located on the N-terminal in FADD and TRADD. At the subsequent resolution and activation of procaspase- 8 , caspase- 8 can then initiate a proteolytic cascade through caspases-3, -6 and -7 that cause apoptosis [5].

Results of this study indicate that oral administration polyphenol of $P$. Macrocarpa may increase caspase- 8 expression in the receptor mortality pathway in the treatment group compared with the control group (not treated) in the mice. This result is shown through statistical tests with $(p=0.000)$. Because of the $p$ value $<0.05(0.000)$, the polyphenols of $P$. Macrocarpa can harbor cell apoptosis by increasing the caspase- 8 expression in Balb/c.

Based on various literatures, caspase- 8 in lung cancer is associated with apoptosis in non-small cell lung cancer [23]. After ligation, the death receptors interact in wide variations with adapter proteins through the homologous mortality domain, it includes FADD and CRADD. Casp- 8 and Casp-9 were recruited to adapter proteins through homologous interactions of mortality effector domain [24] and required for signal transduction of death. The death receptor complexes, adapter proteins, and apical caspases are called the death-inducing signal complex or DISC and their attachment is important for caspase-8 signal transduction after ligation of the death receptor. The encounter with mitochondrial cascade takes place through the process and truncation of the proapoptotic BID produces the BAX-dependent MOMP. This cascade thus strengthens apoptosis through apoptosome [23].

Results of this study are similar to those of [25] by testing isothiocyanate to cause caspase- 8 activation of human leukemia HL60 cells. In addition, EGCG is able to be directly bound to death receptor Fas to initiate caspase- 8 activation [26]. While [27], seen an increase in caspase- 8 in human hematoma cells. When cellular stress occurs (e.g. DNA damage), the proapoptotic protein in the cytosol will be activated, then it will lead to a mitochondrion permeability transition pores (MPTP) transition. So in the end, the cytochrome $\mathrm{c}$ located within the mitochondria will be released into the cytosol. In the presence of cytosolic dATP (deoxyadenosine triphosphate) or ATP, there is oligomerization of apoptotic protease activation factor-1 (Apaf-1). Together with cytosolic procaspase, dATP and cytochrome $\mathrm{c}$, the oligomerized Apaf-1 can form the formation of a massive complex known as apoptosome. N-terminal Apaf-1 and prodomain procaspase- 9 both have CARD, with complementary shapes and reversed contents. Both interact with each other through CARD and form a complex in the proportion of 1:1. Activated Caspase- 9 can 
then activate procaspase- 3 and procaspase-7. Activated Caspase will then activate procaspase- 9 and form a positive reciprocal activation path [21]; [28].

In this study, oral administration polyphenolic $p$. Macrocarpa could increase caspase- 9 expression in the treatment group compared with the control group (not treated) in mice. This result is shown through statistical tests with $(p=0.000)$. Because of the $p$ value $<0.05(0.000)$, the crown polyphenols of the gods can harbor cell apoptosis by increasing the caspase- 9 expression in Balb/c.

The results of this study support previous studies conducted by [29] in which the administration of black tea polyphenols in the treatment group increased the expression of caspase-9 compared to the control group [29]. This increase is related to the role of polyphenols in inhibiting the activation of procaspase-9 which may lead to activation of caspase- 9 thus activating caspase-3.

\section{Conclusions and Recommendations}

Based on the analysis of the results and discussion of the research, it can be concluded that there is an increase in expression of caspase- 8 and caspase- 9 expression in the mice of Balb/c induced Benzo(a)Pyrene.

There is a need to conduct further research to find out more on the role of polyphenols of P. Macrocarpa as anti-cancer by evaluating on the receptor path of death, it is necessary to measure the FAS protein that contributes to the increase in caspase- 8 . In addition, in this pathway, TNF- $\alpha$ is also required to contribute to NF- $\kappa \beta$ that causes apoptosis. The study is still limited to molecular marker of cell proliferation and apoptosis. For that, further research is needed related to molecular changes in cancer so that testing can be continued in clinical research for patients with lung cancer.

\section{Acknowledgement}

1. Laboratory cheif LPPT-IV Gadjah Mada University of Yogyakarta. Prof. Dr. drh. Pudji Astuti, M.P who has allowed and assisted in conducting animal research in laboratory experiments.

2. Laboratory cheif Anatomical Pathology Faculty of Medicine Universitas Gadjah Mada dr. Prijono Tirtoprodjo, Sp.PA (K) who has assisted in making preparations with HE painting, performed IHC cuts in the laboratory.

3. Laboratory cheif Anatomical Pathology dr. Sardjito Yogyakarta dr. Prijono Tirtoprodjo, Sp.PA(K) who has assisted in conducting IHC painting in the Laboratory.

4. Mr. Yunadir and Mr. Sumantri in Anatomical Pathology UGM and Mrs. Agustine Siswantono, in Anatomical Pathology RSUD dr. Sardjito is very helpful in immunohistochemical rolling and painting during the study.

5. Dr. dr. Harijadi, Sp.PA(K), staff Anatomical Pathology Universitas Gadjah Mada Yogyakarta who has taken the time to read the results of the research.

\section{REFERENCES}

[1] Li Y, Li X, Hussain M \& Sarkar FH. Regulation of microtubule, apoptosis, and cell cycle-related genes by Taxotere in prostate cancer cells analyzed by microarray. Neoplasia 2004, 6(2): 158-167.

[2] Choudhuri T, Pal S, Agwarwal ML, Das T, Sa G. Curcumin induces apoptosis in human breast cancer cell through p53-dependent Bax induction. FEBS Letters 2002; 512: 334-340.

[3] Vousden KH, Lu X. Live or let die: the cell's response to p53. Nat Rev Cancer. 2002 Aug; 2(8): 594-604.

[4] Shivapurkar N, Reddy I, Chaudhary PM, Gazdar AF. Apoptosis and lung cancer: a review. J. of Cell. Biochem. $2003 ; 88 ; 885-898$.

[5] Crighton D and Ryan KM. Splicing DNA-damage responses to tumor cell death. Biochimica et Biophysica Acta 2004; 1705: 3-15.

[6] Bode AM, Dong Z. Targeting signal transduction pathways by chemopreventive agents. Mutat. Res 2004b; 555: 33-51.

[7] Zhai S, Dai R, Friedman F, Vestal R. Comparative inhibition of human cytochromes p450 1A1 and $1 \mathrm{~A} 2$ by flavonoids. Drug Metabolism and Disposition 2008; 26: 989-992.

[8] Singh RP, Agarwal P, Yim D, Agarwal C, Agarwal R. Acacetin inhibits cell growth and cell cycle progression and induced apoptosis in human prostate cancer cells: strukture-activity relationship with linarin and linarin acetate. Carcinogenesis 2005; 26: 845-85.

[9] Frei B and Higdon J. V. Antioxidant activity of tea polyphenols in vivo: evidence from animal studies. Journal of Nutrition 2003; 133: 3275S-3284S.

[10] Wardhani HR, Nawawi A, Adnyana KI. Bioenophenone glokosida from red fruit of Paleria macrocarpa and activity to DPPH and murine leukemia P-388 cells. Indonesian bulletin about natural chemical products 2004; 4 (2): 67-70.

[11] Rahmawati E, Dewoto HR, Wuyung PE. Anticancer activity study of ethanol extract of mahkota dewa fruit pulp (Phaleria macrocarpa (Scheff.) Boerl.) in $\mathrm{C} 3 \mathrm{H}$ mouse mammary tumor induced by transplantation. Med. Indonesia 2006; 15(4): 217-222.

[12] Widyasari A, Riastiti Y, Astuti 1, Susilowati R, Harijadi. Efect of Paleria macrocarpa to expretion caspase-3 activity to cel line Ca colon WiDr. Berkala llmu Kedokteran 2006; 38(1): 24-29.

[13] Faried A, Kurnia D, Faried L. S, Usman N, Miyazaki T, Kato H, Kuwano H. Anticancer effects of gallic acid isolated from Indonesian herbal medicine, Phaleria 
macrocarpa (Scheff.) Boerl. on human cancer cell lines. Int J Oncol, 2007; 30: 605-13.

[14] Lisdawati E. Buah mahkota dewa (Phaleria macrocrapa (Scheff.) Boerl.), toksisitas, efek antioksidan dan efek antikanker berdasarkan uji penapisan farmakologi. J. Med. Indo. 2002; 9(3): 34-39.

[15] Watuguly T, Yotopranoto S, Subekti S. Toxicity test of bioinsecticide extracts of Phaleria papuana to mortalitas stadium larva Aedes aegypti Linn. In laboratorium. Maj. Ked. Trop. Indo. 2005; 17(1): 33-46.

[16] Murwanti R, Meiyanto E, Kristina S. A. Anticarcinogenic effect of ethanolic extract of Curcuma zedoaria Rosc. on the growth of lung tumor induced by benzo(a)pyrene. Majalah Farmasi Indonesia 15(1): 156-161.

[17] Banerjee S, Manna S, Mukherjee S, Pal Debalina, Panda $\mathrm{CKr}$, Das S. Black tea polyphenols restrict benzo(a)pyrene-induced mouse lung cancer progression through inhibition of Cox-2 and induction of caspase- 3 expression. Asian Pacific J Cancer Prev 2006a; 7: 661-666.

[18] Banerjee S, Panda CKr, Das S. Clove, a potential chemopreventive agent for lung cancer. Carcinogenesis 2006b; 27(8): 1654-1654.

[19] Mohan KPVC, Devaraj H, Prathiba D, Hara Y, Nagini S. Antiproliferative and apoptosis inducing effect of lactoferrin and black tea polyphenol combination on hamster buccal pouch carcinogenesis. Bioch. et Biophy. Acta 2006; 1760(10): 1536-44.

[20] Letchoumy PV, Mohan KVPC, Prathiba D, Hara Y, Siddavaram N. Comparative evaluation of antiproliferative, antiangiogenic and apoptosis inducing potential of black tea polyphenols in the hamster buccal pouch carcinogenesis model. Journal of Carcinogenesis 2007; 6(19): 1-13.

[21] Arnoult D, Gaume B, Karbowski M, Sharpe JC, Cecconi F,
Youle RJ. Mitochondrial release of AIF and EndoG requires caspase activation downstream of Bax/Bak-mediated permeabilization. EMBO J 2003, 22: 4385-4399.

[22] Viktorsson K and Lewensohn R. Apoptotic signaling pathways in lung cancer. Journal of Thoracic Oncology 2007; 2(3): 175-179.

[23] Fennell DA. Caspase regulation in non-small cell lung cancer and its potential for therapeutic exploitation. Clinical Cancer Research 2005; 11: 2097-2105.

[24] Kischkel FC, Lawrence DA, Tinel A. Death receptor recruitment of endogeneus caspase-10 and apoptosis initiation in the absence of caspase-8. J Biol Chem 2001; 276: 46639-46.

[25] Zhang Y. Cancer-preventive isothiocyanates: measurement of human exposure and mechanism of action. Mutat. Res. 2004; 555: 173-190.

[26] Hayakawa S, Saeki K, Sazuka M, et al. Apoptosis induction by epigallocatechin gallate involves its binding to Fas. Biochem Biophys Res Commun 2001, 285: 1102-6.

[27] Selvendiran K, Koga H, Ueno T, Yoshida T, Maeyama M, Torimura T, Yano H, Kojiro M, Sata M. Luteolin promotes degradation in signal transducer and activator of transcription 3 in human hepatoma cells: an implication for the antitumor potential of flavonoids. Cancer Res 2006; 66: 4826-34.

[28] Johnson CR and Jarvis WD. Caspase-9 regulation: An update. Apoptosis 2004; 9: 423-427.

[29] Letchoumy PV, Mohan KVPC, Prathiba D, Hara Y, Siddavaram N. Comparative evaluation of antiproliferative, antiangiogenic and apoptosis inducing potential of black tea polyphenols in the hamster buccal pouch carcinogenesis model. Journal of Carcinogenesis 2007; 6(19): 1-13. 